УДК 159.9: 37.011 .3

DOI https://doi.org/10.32838/2709-3093/2021.3/17

Василенко Л.П.

Дрогобицький державний педагогічний університет імені Івана Франка

Василенко І.Я.

Львівський національний університет імені Івана Франка

\title{
ГОТОВНІСТЬ ВИКЛАДАЧІВ ДО ІННОВАЦІЙНОЇ ДІЯЛЬНОСТІ В ОСВІТНЬОМУ ПРОЦЕСІ ВИЩОЇ ШКОЛИ
}

Готовність викладачів до інновачійної діяльності є важливою умовою модернізаиії освітньої системи. Від готовності викладача прийняти і реалізувати інноваиії в освітньому процесі вищої школи залежить якість надання освітніх послуг і як наслідок - результат освіти. Однак у науковій літературі недостатньо досліджень, які розкривають суть иього поняття. У статті розкриті науково-теоретичні аспекти проблеми готовності до інновачійної діяльності, конкретизовано зміст поняття «психологічна готовність викладача вищої школи до інновачійної діяльності». Готовність викладача до інновачійних перетворень у навчальнопрофесійній діяльності розглядається як необхідний складник особистісно-професійного розвитку. Проаналізовано функиії готовності викладача до інновачійної діяльності, виділено властивості особистості, які впливають на успішність інновачійної діяльності (інтелектуальна активність, креативність, толерантність до невизначеності, самостійність, інічіативність і гнучкість, мотивація досягнення успіху, спрямованість на зміни, відкритість новому досвіду та інші). Обтрунтовано показники та критерії готовності (мотиваційний, когнітивний, проиесуальний, креативний). Розкрито основні компоненти готовності викладачів до інноваційних перетворень: мотивачійно-ціннісні настанови, професійна компетентність, особистісна готовність, технологічна готовність. Виділено складники психологічної готовності викладача до інновацій в освітньому процесі вищої школи: виявлення особистісно-професійних особливостей студентів, на динаміку яких спрямована інноваційна діяльність; формування мотивів, щзо зумовлюють умови професійної самореалізачії в інновачійній діяльності; врахування мотивачії студента під час переходу від традиційного до інновачійного навчання; подолання викладачем традииійних настанов; оволодіння інноваційними технологіями; розвиток рефлексії, усвідомлення ступеня відповідності індивідуальних характеристик сучасним вимогам до особистості викладача, який ефективно працює в руслі інновачійного прочесу.

Ключові слова: інновачія, інноваційні технологї, інновачійна діяльність, готовність до інновачій, психологічна готовність викладача до інноваційної діяльності.

Постановка проблеми. Підвищена увага держави до проблем якості та ефективності освіти вимагає оновлення іiі цілей, змісту, інноваційної діяльності. Має місце настанова на різнобічний розвиток людини як суб'єкта діяльності, готової до творчої, ініціативної, відповідальної роботи, здатної використовувати всі свої потенційні можливості. Становлення інноваційних процесів у вищій школі значною мірою визначається як рівнем професіоналізму викладачів, так і їх готовністю до інноваційної діяльності.

Аналіз останніх досліджень і публікацій. Готовність людини до діяльності розглядається в теорії і практиці освіти 3 різних позицій: як умова успішного виконання діяльності; як активність, налаштування особистості на майбутню діяльність; як концентрація або миттєва мобілізація сил особистості, спрямована в потрібний момент на здійснення певних дій; як комплекс здібностей, що включають різні властивості і якості особистості (А.Д. Ганюшкин, М.I. Дьяченко, В.М. Мясищев та іншы). Увагу багатьох науковців привертає явище психологічної готовності до здійснення професійної діяльності (О.І. Бондарчук, О.П. Коханова, Б.Г. Климов, В.О. Крутецький, В.П. Чумакова та інші). Більшість авторів сходяться на думці, що психологічна готовність - це комплекс індивідуально-психологічних особливостей, що варіюють залежно від контексту діяльності (О.С. Толков, А.А. Моца та інші). Психологічну готовність до інноваційної діяльності пов'язують 3 такою інтегральною 
характеристикою, як інноваційний потенціал особистості (Ю.О. Власенко, Ю.Л. Колесниченко, В.С. Клочко та інші). Стосовно до людини поняття «потенціал» відображає ресурсну частину (можливості) і ступінь готовності людини реалізувати ці можливості.

Постановка завдання. Мета статті - виділити та обгрунтувати складники психологічної готовності викладачів до інноваційної діяльності в освітньому процесі вищої школи.

Виклад основного матеріалу дослідження. Феномен психологічної готовності до інноваційної діяльності є багатоплановим системним утворенням, у якому не просто відображаються операційні аспекти професійної підготовленості фахівця до інновацій, а й проявляються особистісні характеристики, що включають комунікативні, інтелектуальні, емоційно-вольові якості, а також мотивацію. Мотивація відображає спрямованість на інновації: соціокультурні смисли, ставлення до професійної діяльності, професійні інтереси, кар'єрну спрямованість.

Психологічна готовність до інноваційної діяльності - це системне утворення, що характеризує цілісний прояв особистості, інтегрує творче ставлення до діяльності, спрямованість на розвиток і саморозвиток; знання, вміння та навички, необхідні для виконання такої діяльності: інтелектуальні, емоційні та вольові якості особистості [9].

Дослідники виділяють функції психологічної готовності до інноваційної професійної діяльності: гностична, інтегративна, прогностична та ціннісно-орієнтовна [4; 6]. Спрямованість на особистісний саморозвиток і розвиток у професійній діяльності, здатність до навчання протягом життя, надбання нових компетенцій $є$ гностичним змістом психологічної готовності фахівця. Інтеграційна функція готовності відображає системний характер цього психологічного феномена і являє собою об'єднання компонентів психологічної готовності в єдине особистісне утворення. Прогностична функція пов'язана 3 можливостями антиципації, прогнозу успішності вибору дій, рішень, наявністю стратегічного бачення як концептуальної основи прийняття рішень у кар'єрі, професійних ситуаціях діяльності та поведінки. Ціннісно-орієнтовна функція готовності до інноваційної діяльності відображає мотиваційносмисловий характер ставлень особистості до інновацій у професійній діяльності і взаємодій у соціально-професійному середовищі. Психологічна готовність викладачів до інноваційної професійної діяльності визначається специфікою діяльності та відображає цю специфіку в змістовному наповненні структурних компонентів [8; 9].

До властивостей особистості, які впливають на успішність інноваційної діяльності, включають інтелектуальну активність, креативність, толерантність до невизначеності, самостійність, ініціативність і гнучкість. Гнучкість і самостійність, як функціонально-стильові особливості системи саморегуляції інноваційної діяльності, пов'язані 3 уміннями і навичками планувати роботу, моделювати зовнішні і внутрішні умови діяльності адекватно до цілей і задач діяльності. Інноваційна професійна діяльність вимагає також від фахівця прояву психічної стійкості й адаптивності особистості, які визначаються високим рівнем гнучкості і самостійності регуляторної системи. Мотиваційно-смислові характеристики інноваційної професійної діяльності пов'язані 3 мотиваційною активністю - широтою науковопізнавальної мотивації особистості, соціальними настановами та інтересом до інновацій, мотивацією досягнення успіху, а також з мотиваційною гнучкістю - спрямованістю на зміни, відкритістю до нового досвіду.

Готовність викладача до інноваційної діяльності є сукупністю взаємозв'язаних індивідуально-психологічних особливостей його особистості, професійних та спеціальних знань і умінь у сфері інноватики, які визначають прагнення до оволодіння новим способом і прийомами виконання діяльності, певними компетенціями, що відповідають цьому виду діяльності. Психологічну готовність викладачів до інноваційної професійної діяльності ми розглядаємо як системне особистісне утворення, що забезпечує включеність і ефективність інноваційної професійної діяльності, що інтегрує: знання, вміння, навички; систему значущих цінностей і професійних мотивів; професійно важливі якості інноваційного фахівця. Під час переходу від традиційного до інноваційного навчання слід враховувати і мотивацію викладача. Саме поняття інновації пов'язано з прагненнями, схильностями, потребами, а це означає, що в основі мотивації досягнення успіху викладача лежить потреба i прагнення до підвищення ефективності власної діяльності, що спонукає його звернутися до інноваційних методів навчання. У педагогічній психології зазначається, що ефективність діяльності і комфортний стан педагога забезпечуються оптимальним рівнем інтелектуального розвитку, гнучкістю і конвергентністю мислення, активністю, високим темпом реакції, лабільністю, емоційною стійкістю, високим рівнем саморегуляції. 
Показниками готовності викладача до реалізації інноваційних освітніх технологій виступають: особистісно-значущий сенс реалізації цих технологій; сформованість методологічних і теоретичних знань; сформованість узагальнених умінь: a) проєктувальних: виявляти проблему, ставити мету, визначати показники результатів, проєктувати технологію на конкретне освітнє середовище, реалізовувати на практиці елементи або всю технологію; б) управляти самокерованою навчальною діяльністю студентів в освітньому процесі. Узагальненими показниками психологічної готовності до інноваційної професійної діяльності є активність і гнучкість.

Виходячи із сутності готовності викладача вишу до інноваційної діяльності, критеріями цього стану є: мотиваційний (спрямованість особистості на реалізацію себе в інноваційній діяльності, сприйнятливість до інновацій, прагнення до високих досягнень в інноваційній діяльності, а також цінність самовдосконалення в ній); когнітивний (наукова компетентність і доцільність здійснюваних дій); процесуальний (сформованість у викладачів умінь щодо реалізації інновацій); креативний (гнучкість, відкритість щодо інновацій, творча уява, критичність мислення).

У процесі вирішення завдань втілення інновацій в освітній процес вищої школи важливо виділити основні вимоги до діяльності викладача. Ми виділили такі: а) викладач має бути творчою особистістю; б) викладач повинен мати фундаментальні наукові знання 3 предмету, який він викладає; в) має бути переконаний, що кожен зі студентів здатний до творчості; г) має володіти всім арсеналом освітніх технологій, використовуваних у виші. Для практичного вирішення проблеми підвищення інноваційної готовності викладача необхідна здатність викладача до наукової педагогічної рефлексії свого і чужого досвіду, вміння i можливість опановувати ефективні освітні технології, відповідна морально-психологічна атмосфера в вишах, орієнтована на навчальний процес як професійну творчість.

Науково-теоретичні аспекти та провідні тенденції в розвитку інноваційних процесів, а також проведений аналіз інтеграційних якостей, які складають сутнісні риси особистості інноваційного типу, дозволяє розглядати готовність викладачів до інноваційних перетворень у навчальнопрофесійній діяльності як необхідного складника особистісно-професійного розвитку, що забезпечує формування нових морально-гуманістичних позицій, якостей, безперервність росту професіоналізму [1]. На основі аналізу досліджень $[2 ; 5 ; 7]$ визначаємо такі компоненти готовності викладачів до інноваційних перетворень: мотиваційно-ціннісні настанови, професійну компетентність, особистісну готовність, технологічну готовність.

Змістом мотиваційно-иіннісних настанов є: усвідомлення себе як особистості і професіонала; усвідомлення нових професійних цілей; усвідомлення значущості власної професійної діяльності, націленість на результат; наявність професійної позиції; прагнення до саморозвитку та професійних досягнень; орієнтація на творчу професійну діяльність і якість; позитивний настрій на перетворювальну професійну діяльність.

Професійна компетентність, як компонент готовності викладачів до інноваційних перетворень, включає розвиток професійних здібностей: дослідні (аналітичні, пізнавальні); проєктувальні (цілепокладання, планування, моделювання та конструювання випереджаючого, проблемного, системного змісту навчання та освітнього процесу); організаційні (пунктуальність, працездатність, дисциплінованість); комунікативні (побудова доброзичливих, об'єктивно справедливих стосунків); рефлексивні (усвідомлення себе і очікувань учнів: що змінилося, який успіх отриманий, відкриття нових досягнень, альтернатив).

До особистісної готовності належать:

- особистісні якості (здатність брати на себе відповідальність, системність мислення, самопізнання, прагнення до творчої самореалізації, стресостійкість, адаптивність, самостійність, ініціативність, впевненість в успіху, морально-вольова саморегуляція, ерудованість, тактовність, володіння собою, витриманість та інші) ;

- особистісна, загальна і професійна культура: культура викладання (логічність, чіткість, виразність, правильність, точність мови); професійно-термінологічна грамотність, стиль поведінки і взаємодії в освітньому процесі.

Технологічна готовність включає: вміння організовувати i спеціально створювати розвивальне освітнє середовище; побудова освітнього процесу на основі сучасних технологій навчання: модульне, проблемне, пошукове, проєктне й інші; володіння методами реалізації інновацій, здійснення нововведень 3 максимальною ефективністю.

Готовність викладачів до інноваційної освітньої діяльності включає: здатність бачити світ цілісно, в єдності його різноманіття, активно брати участь у змінах, які відбуваються в системі вищої школи, 
забезпечуючи перетворення освітнього середовища (процесу) і змісту з вихідного стану в необхідний; здатність відповідати змінам, які мають місце в суспільстві, задовольняти потребу студентів у якісній освіті сьогодні для майбутнього; володіння новими технологіями, способами або методикою їх реалізації на практиці; володіння викладачем професійними компетенціями та особистісними здатностями, необхідними для виконання вимог щодо реалізації вибраної освітньої технології; рефлексія своєї діяльності з позицій інноваційного підходу; створення позитивного емоційного фону навчання; реалізація принципу партнерства, співпраці, діалогу між викладачем i студентом; створення атмосфери активної співтворчості студентів, довірливі, позитивні стосунки, співробітництво в процесі спілкування викладача зі студентами та студентів між собою; включення зовнішньої і внутрішньої мотивації діяльності, а також взаємомотивації студентів.

Щоб бути готовим до інноваційної діяльності, потрібно володіти якостями і здібностями, що забезпечують організацію освітнього процесу в режимі розвитку. Саме розвиток забезпечує спільність і єдність освітнього процесу, оптимальні умови організації освітнього простору і взаємодії викладача зі студентами, сприяє системному освоєнню студентами змісту предметної сфери i безперервному оволодінню культурою через освоєння сукупності необхідних предметних знань, здібностей у конкретній галузі, що дозволяють органічно включати їх у свою життєдіяльність. Під час використання інноваційних методів навчання змінюється роль викладача - від «транслятора» знань через роботу «майстра», що організує інноваційний педагогічний процес, до позиції «консультанта», який разом зі студентом проєктує його майбутню професійну діяльність. Удосконалюючи свою творчу вправність, викладач удосконалює освітній процес, професійну майстерність, підвищуючи навчально-пізнавальну діяльність студентів, яка має особливе значення в організації інноваційної діяльності $[2 ; 5]$.

Як показали результати проведеного нами дослідження, в процесі впровадження інноваційних технологій викладачі зустрічаються 3 труднощами, які потребують їх психологічної перебудови, зокрема формування внутрішньої готовності до подолання психологічних бар'єрів у процесі впровадження інновацій. Водночас організація навчального процесу в інноваційному режимі передбачає відповідний стиль педагогічної діяльності, заснований на співпраці викладача і студента. У зв'язку з цим мотиваційний показник інноваційної готовності викладача вузу виступає як основний, він забезпечує відмову від старих стереотипів педагогічної діяльності, установок, звичок, дозволяє вдосконалювати рівень готовності викладацького складу до впровадження інновацій в освітній процес. Не менш важливими показниками в структурі інноваційної готовності викладача виступають такі, як когнітивний i емоційний, які вказують на рівень його інформованості та вміння аналізувати результати власної професійної діяльності. Таким чином, готовність викладача до застосування інноваційних технологій - це психічний стан, що включає у себе розуміння цілей інноваційної діяльності, високу мотивацію, оцінку і впевненість у їі результативності.

У процесі розвитку готовності до впровадження інноваційних форм навчання необхідно враховувати ряд психолого-педагогічних умов, серед яких найважливіші: особистісні особливості викладачів, вектор їх професійної спрямованості, орієнтованість на впровадження нововведень, мотивація до самоосвіти.

Висновки. Складниками психолого-педагогічної готовності викладача до інноваційної діяльності є: формування мотивів, що зумовлюють умови професійної самореалізації в інноваційній діяльності; врахування мотивації студента під час переходу від традиційного до інноваційного навчання; розвиток комунікативної компетентності через усвідомлення власних стереотипів поведінки, вчинків, дій, а також через оволодіння практичними навичками i стратегіями особистісного спілкування; подолання викладачем традиційних настанов; оволодіння інноваційними технологіями; розвиток рефлексії, усвідомлення ступеня відповідності індивідуальних характеристик сучасним вимогам до особистості викладача, який ефективно працює в руслі інноваційного процесу.

\section{Список літератури:}

1. Василенко Л.П., Василенко І.Я. Впровадження технології особистісно-професійного розвитку майбутнього педагога в практику викладання психологічних дисциплін. Науковий вісник Херсонського державного університету. Серія: Психологічні науки. Випуск 6. Том 2, 2017. С. 12-17.

2. Коваль Т.I. Підготовка викладачів вищої школи: інформаційні технології у педагогічній діяльності: Навч.-метод. посібн. Київ : Вид. центр КНЛУ, 2009. 380 с. 
3. Коржуев А.В., Попков В.А. Традиции и инновации в высшем профессиональном образовании. Москва : МГУ, 2003. 300 с.

4. Курбатов С.В. Освітні інновації: контури майбутнього. Феномен інноваиій: освіта, суспільство, кульmура / За ред. В.Г. Кременя. Київ : Педагогічна думка. 2008. С. 265-304.

5. Моца А.А. Теоретико-методичний аспект інноваційного розвитку вищої освіти України. Міжнародний науковий вісник: збірник наукових праиьь / ред. кол. І.В. Артьомов та ін. Ужгород : ДВНЗ «УжНУ», 2015. $316 \mathrm{c}$.

6. Сучасні освітні технології у вищій школі: Матеріали міжнар. наук.-метод. конф. (Київ, 1-2 листопада 2007 року) : Тези доповідей: У 2 ч. Ч. 2 / Відп. ред. А.А. Мазаракі. Київ : Київ. нац.торг. -екон. ун-т, 2017. $259 \mathrm{c}$.

7. Толков О.С. Формування психологічної готовності персоналу вищої школи до діяльності в умовах соціально-економічних змін [Рукопис] : Дис. ... канд. психол. наук: 19.00.10 / О.С. Толков; Наук. кер. Л.М. Карамушка; Ін-т психології імені Г.С. Костюка НАПН України. Київ : [б. и.], 2012. 343 с

8. Чудакова В.П. Модель експертизи і корекції внутрішньої психологічної готовності персоналу освітніх організацій до інноваційної діяльності - чинник формування конкурентоздатності особистості [Текст] Освіта і розвиток обдарованої особистості: Щомісячний науковометодичний журнал. 2013. № 10 (17) (жовтень). С. 52-61.

9. Яголковский С.Р. Психология инноваций: подходы, модели, процессы: монография. Москва, 2010. $264 \mathrm{c}$.

\section{Vasylenko L.P., Vasylenko I.Ya. READINESS OF TEACHERS FOR INNOVATIVE ACTIVITIES IN THE EDUCATIONAL PROCESS OF HIGHER EDUCATION}

The readiness of teachers to innovate is an important condition for the modernization of education at the present stage. The quality of educational services and the result of education depend on the readiness of a teacher to accept and implement innovations in the educational process of higher education. However, in the scientific literature there are not enough studies that reveal the essence of this concept. The article reveals the scientific and theoretical aspects of the problem of readiness for innovation, specifies the meaning of the concept of psychological readiness of a high school teacher for innovative activities. The readiness of a teacher for innovative transformations in educational and professional activities is considered to be a necessary component of personal and professional development. The functions of the teacher's readiness for innovative activities are analyzed, the personality traits that influence the success of innovative activity are distinguished, namely intellectual activity, creativity, tolerance to uncertainty, independence, initiative and flexibility, motivation to succeed, focus on change, openness to new experience, etc. Such indicators and criteria of readiness as motivational, cognitive, procedural, creative are substantiated. The main components of a teacher's readiness for innovative transformations are revealed: motivational and valuation guidelines, professional competence, personal and technological readiness. The components of a teacher's psychological readiness for innovations in the educational process of higher education are identified, particularly the identification of personal and professional characteristics of students, the dynamics of which are aimed at innovative activities; the formation of motives that determine the conditions of professional self-realization in innovation taking into account the motivation of a student in the transition from traditional to innovative learning, overcoming traditional guidelines by a teacher, mastering innovative technologies, the development of reflection, awareness of the degree of compliance of individual characteristics with modern requirements for the personality of a teacher who works effectively together with the innovation processes.

Key words: innovation, innovative technologies, innovative activity, readiness for innovations, psychological readiness of a high school teacher for innovative activity. 